\title{
CARBON DIOXIDE AND METHANE FLUXES BY A FOREST SOIL UNDER LABORATORY-CONTROLLED MOISTURE AND TEMPERATURE CONDITIONS
}

\author{
RICHARD D. BOWDEN, ${ }^{1 *}$ KATHLEEN M. NEWKIRK ${ }^{2}$ and GINA M. RULLO ${ }^{1}$ \\ ${ }^{1}$ Allegheny College, Department of Environmental Science, Meadville, PA 16335, U.S.A. and ${ }^{2}$ The \\ Ecosystems Center, Marine Biological Laboratory, Woods Hole, MA 02543, U.S.A.
}

\author{
(Accepted 17 September 1997)
}

\begin{abstract}
Summary - Carbon dioxide and methane are important greenhouse gases whose exchange rates between soils and the atmosphere are controlled strongly by soil temperature and moisture. We made a laboratory investigation to quantify the relative importance of soil moisture and temperature on fluxes of $\mathrm{CO}_{2}$ and $\mathrm{CH}_{4}$ between forest soils and the atmosphere. Forest floor and mineral soil material were collected from a mixed hardwood forest at the Harvard Forest Long-Term Ecological Research Site (MA) and were incubated in the laboratory under a range of moisture (air-dry to nearly saturated) and temperature conditions $\left(5-25^{\circ} \mathrm{C}\right)$. Carbon dioxide emissions increased exponentially with increasing temperature in forest floor material, with emissions reduced at the lowest and highest soil moisture contents. The forest floor $\mathrm{Q}_{10}$ of 2.03 (from $15-25^{\circ} \mathrm{C}$ ) suggests that $\mathrm{CO}_{2}$ emissions were controlled primarily by soil biological activity. Forest floor $\mathrm{CO}_{2}$ emissions were predicted with a multiple polynomial regression model $\left(r^{2}=0.88\right)$ of temperature and moisture, but the fit predicting mineral soil respiration was weaker $\left(r^{2}=0.59\right)$. Methane uptake was controlled strongly by soil moisture, with reduced fluxes under conditions of very low or very high soil moisture contents. A multiple polynomial model accurately described $\mathrm{CH}_{4}$ uptake by mineral soil material $\left(r^{2}=0.81\right)$, but only weakly $\left(r^{2}=0.45\right)$ predicted uptake by forest floor material. The mineral soil $\mathrm{Q}_{10}$ of 1.11 for $\mathrm{CH}_{4}$ uptake indicates that methane uptake is controlled primarily by physical processes. Our work suggests that inclusion of both moisture and temperature can improve predictions of soil $\mathrm{CO}_{2}$ and $\mathrm{CH}_{4}$ exchanges between soils and the atmosphere. Additionally, global change models need to consider interactions of temperature and moisture in evaluating effects of global climate change on trace gas fluxes. (C) 1998 Elsevier Science Ltd. All rights reserved
\end{abstract}

\section{INTRODUCTION}

Carbon dioxide and methane are greenhouse gases whose atmospheric concentrations have been increasing over the last several centuries (Prather et al., 1996; Schimel et al., 1996). Methane is of increasing concern because it has a radiative potential 26 times more effective than $\mathrm{CO}_{2}$ (Lilieveld and Crutzen, 1992), and because it influences the oxidative potential of the atmosphere (Thompson, 1992).

Soils are major global sources and sinks of $\mathrm{CO}_{2}$ and $\mathrm{CH}_{4}$ and thus play an important role in regulating atmospheric concentrations of these gases (Mooney et al., 1987; Melillo et al., 1989). Soil respiration by terrestrial ecosystems contributes 50 $75 \times 10^{9} \mathrm{t} \mathrm{C} \mathrm{y}^{-1}$ (Kicklighter et al., 1994) to the atmosphere, which is an order of magnitude greater than the annual increase in atmospheric carbon (Watson et al., 1990). Globally, consumption of atmospheric methane by both methanotrophic and nitrifying bacteria in aerobic soil (Bedard and Knowles, 1989) is $1.5-4.5 \times 10^{7} \mathrm{t} \mathrm{Cha}^{-1} \mathrm{y}^{-1}$, repre-

*Author for correspondence. senting 1 to $8 \%$ of the oxidative potential of the atmosphere (Born et al., 1990; Schutz et al., 1990; Prather et al., 1996). Of this total, temperate evergreen and deciduous forests consume up to $37 \%$ (Steudler et al., 1989).

Understanding the dynamics of $\mathrm{CO}_{2}$ and $\mathrm{CH}_{4}$ exchanges between soils and the atmosphere is critical to construction of regional trace gas models and to prediction of trace gas fluxes under models of global climate change. Numerous field studies in temperate forests have shown a strong temporal pattern in $\mathrm{CO}_{2}$ and $\mathrm{CH}_{4}$ fluxes (e.g. Castro et al., 1994; Peterjohn et al., 1994; Castro et al., 1995) that corresponds strongly with seasonal changes in soil moisture and temperature. Temperature is considered the primary predictor of $\mathrm{CO}_{2}$ effluxes, but, not surprisingly, moisture also influences soil respiration rates (e.g. Wiant, 1967; Groffman et al., 1992). Moisture usually exerts strong control over $\mathrm{CH}_{4}$ uptake rates, although inclusion of both moisture and temperature in models can increase predictive capabilities. Lessard et al. (1994) suggested that the strong relationship between moisture and $\mathrm{CH}_{4}$ uptake may mask relationships between tempera- 
ture and uptake, thus it has been difficult to determine the relative importance of these factors.

Using field studies to determine the relative importance of moisture and temperature in controlling flux rates is difficult because soil temperature and moisture usually covary seasonally in temperate ecosystems. Soil temperatures are usually highest by late summer, but strong evapotranspiration potentials usually reduce soil water even if precipitation stays relatively constant. Thus, it is not a straightforward exercise to determine if maximum rates of soil respiration or $\mathrm{CH}_{4}$ uptake in late summer, for example, are due to high temperatures, lower soil moisture, or an interaction of both factors. Understanding the controls of moisture and temperature is important because there is increasing effort to construct regional trace gas models and accurate models cannot be produced if controlling factors are not well understood. To overcome limitations of field-based data in determining the importance of soil moisture and temperature, we did a full-factorial laboratory study to evaluate the relative contribution of each factor, as well as interactions, on $\mathrm{CO}_{2}$ emissions and $\mathrm{CH}_{4}$ uptake by a well-drained temperate forest soil.

\section{MATERIALS AND METHODS}

\section{Site description}

Soil material was collected at the Harvard Forest Long-Term Ecological Research Site in north-central Massachusetts, U.S.A., from an approximately 50-y-old mixed hardwood stand established following abandonment from pastures in the early 1900's (Magill et al., 1997). Total biomass in the stand was $111 \mathrm{tha}^{-1}$, and was dominated by black oak (Quercus velutina Lam.), which comprises $76 \%$ of the total basal area. Remaining vegetation includes black birch (Betula lenta L.), paper birch (Betula papyrifera March.) and red maple (Acer rubrum L.). Soils at the site are of the Canton series (Typic Dystrochrepts) which formed in glacial till. At our site, the Canton soil has a sandy loam texture and a soil $\mathrm{pH}$ of 3.8 (1:1 soil:water); the forest floor is $6.5 \mathrm{~cm}$ thick and has a $\mathrm{pH}$ of 3.3 .

\section{Soil preparation and analysis}

Forest floor and mineral soil $(0-10 \mathrm{~cm})$ were collected from four locations at the site, separated, sieved (forest floor: $5.6 \mathrm{~mm}$; mineral soil: $2 \mathrm{~mm}$ ) to remove rocks and roots, and homogenized so that soil moisture contents could be manipulated accurately. Total water-holding capacity (WHC) of the soil was determined by placing soil into $7 \mathrm{~cm}$ dia by $6 \mathrm{~cm}$ tall polyethylene tubes and saturating them with water. After the tubes were drained for $4 \mathrm{~h}$, WHC was determined gravimetrically by drying soil at $105^{\circ} \mathrm{C}$ to constant weight. For forest floor material, WHC (g water $\mathrm{g} \mathrm{soil}^{-1}$ ) was $3.22 \pm 0.04(\mathrm{SE}$, $n=15$ ) for forest floor and $0.86 \pm 0.02$ (SE, $n=17)$ for mineral soil. Bulk density $\left(\mathrm{g}\right.$ soil cm $\left.\mathrm{cm}^{-3}\right)$ of soil material, determined after soil was placed into the polyethylene tubes, was $0.25 \pm 0.004$ (SE, $n=90$ ) for forest floor and $0.79 \pm 0.01$ (SE, $n=90$ ) for mineral soil.

For each incubation, separate assays were made for forest floor and mineral soil material. Soil material (forest floor: $40 \mathrm{~g}$ oven-dry weight (ODW); mineral soil: $130 \mathrm{~g}$ ODW) was packed into triplicate polyethylene tubes $(7 \mathrm{~cm}$ dia by $6 \mathrm{~cm}$ deep) open at both ends, and was held in the tube with a nylon stocking. Water was added or removed (via air-drying) to approximate the desired percentages of total WHC. Soil moisture contents were adjusted to approximately $20 \%, 40 \%, 60 \%, 80 \%$ and $100 \%$ of WHC immediately prior to each soil conditioning. Soil materials were then conditioned for $48 \mathrm{~h}$ at $5^{\circ}$, $9^{\circ}, 12.5^{\circ}, 16.5^{\circ}, 20^{\circ}$ or $25^{\circ} \mathrm{C}$. Upon completion of each assay, the actual gravimetric soil moisture ( $\mathrm{g}$ water $\mathrm{g}^{-1}$ soil) content (at $105^{\circ} \mathrm{C}$ ) was measured.

\section{Flux measurements}

Trace gas measurements were made by placing soil tubes into 0.91-L air-tight glass jars equipped with sample ports and a variable headspace reservoir that maintained constant pressure within the glass jar by decreasing the headspace by an amount equal to the air volume removed during sampling. After soils were incubated at the desired moisture, they were placed into jars and sealed for $3 \mathrm{~h}$. Headspace gas samples were collected after 0, 1, 2 and $3 \mathrm{~h}$.

Concentrations of $\mathrm{CO}_{2}$ and $\mathrm{CH}_{4}$ were measured using gas-chromatography. Carbon dioxide was analyzed with a Shimadzu GC-8A electron capture gc (Porapak Q column maintained at $45^{\circ} \mathrm{C}$, injector and detector temperatures at $250^{\circ} \mathrm{C}$ (Bowden et al., 1993)), and $\mathrm{CH}_{4}$ concentrations were measured using a Shimadzu GC-8A flame ionization gc (Hayesep Q column, $91 \mathrm{~cm}$ long, $3 \mathrm{~mm}$ dia, stainless steel, $80 / 100$ mesh, maintained at $100^{\circ} \mathrm{C}$, with injector and detector at $130^{\circ} \mathrm{C}$ (Steudler et al., 1989)). Fluxes were calculated using the linear portion of the gas concentration change over the 3-h time step.

\section{RESULTS}

Carbon dioxide fluxes were much greater from forest floor material than from mineral soil material (Fig. 1). Efflux rates from forest floor material increased with temperature, but were lowest under both dry and the wet conditions. In contrast, effluxes from mineral soil material were less responsive to temperature and only slightly responsive to moisture.

Methane uptake rates were related strongly to soil moisture and somewhat to temperature. Uptake rates increased from low values under dry con- 

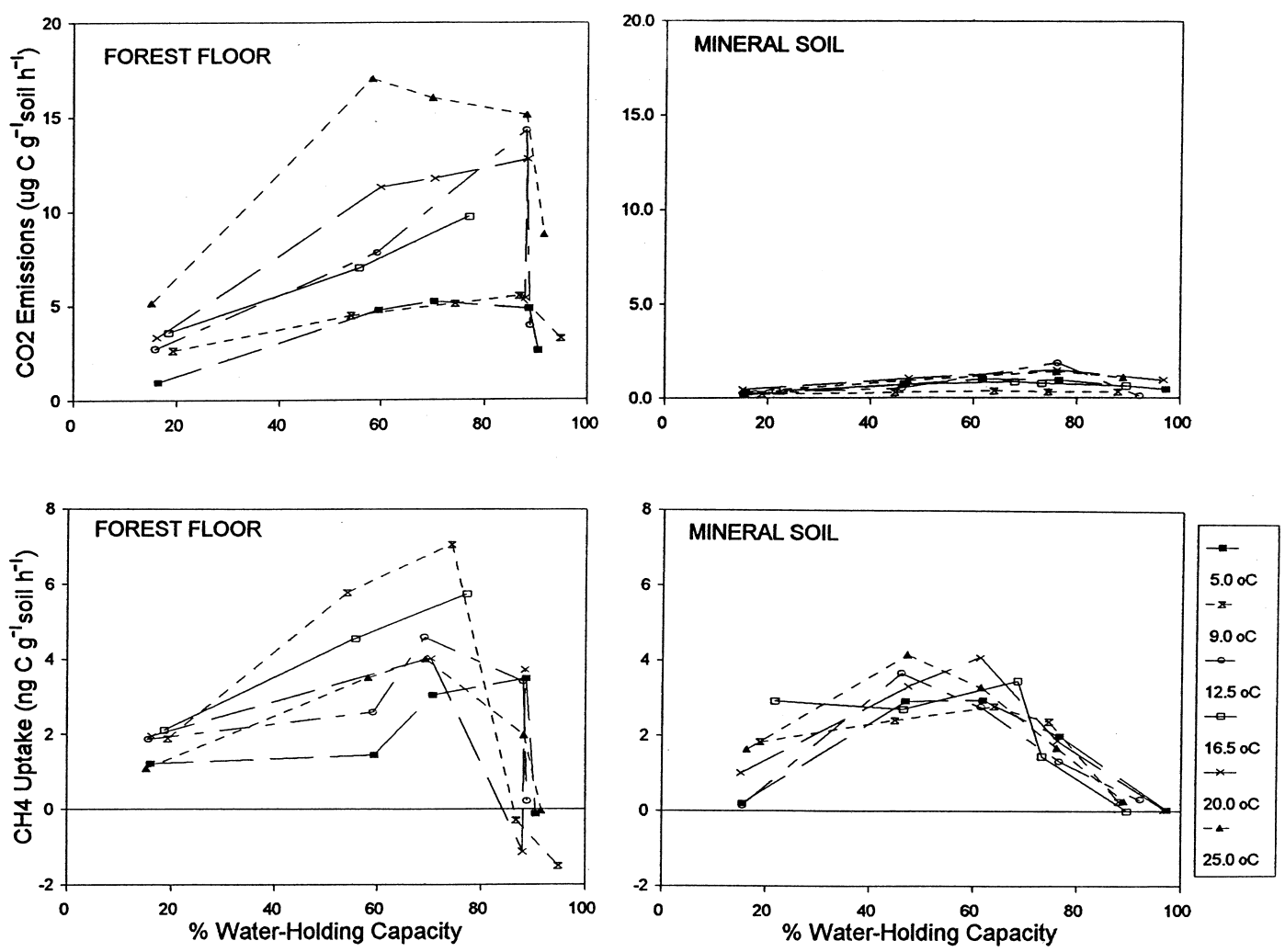

Fig. 1. Fluxes of $\mathrm{CO}_{2}$ and $\mathrm{CH}_{4}$ by laboratory-incubated temperate forest soil

ditions to maximum rates at approximately $70 \%$ of WHC for forest floor material and $50 \%$ for mineral soil. Uptake rates then declined to near zero as soil water content approached $100 \%$ of capacity. Uptake rates were generally highest under the highest temperature conditions, but the influence of temperature was not nearly so strong as that of moisture. Mineral soil and forest floor material generally showed the same rates of uptake.

The relationship of the ln-normally-transformed $\mathrm{CO}_{2}$ effluxes and un-transformed $\mathrm{CH}_{4}$ uptake to moisture and temperature variation was modelled using multiple polynomial regressions (Fig. 2). The model developed for $\mathrm{CO}_{2}$ emissions from forest floor material contained significant contributions from both temperature and moisture (Table 1). For $\mathrm{CH}_{4}$ uptake by mineral soil, only moisture contributed significantly to the model prediction and there were no interaction terms; for the forest floor, there was a significant moisture $\times$ temperature interaction term.

\section{DISCUSSION}

\section{Carbon dioxide}

The relationships we found between temperature and $\mathrm{CO}_{2}$ effluxes are comparable to numerous field studies that have documented strong relationships between temperature and $\mathrm{CO}_{2}$ flux rates in temper- ate soils (e.g. Crill, 1991; Fernandez et al., 1993; Yavitt et al., 1995), including work at the Harvard Forest (Bowden et al., 1993; Peterjohn et al., 1994). The $\mathrm{Q}_{10}$ values (from $15^{\circ} \mathrm{C}$ to $25^{\circ} \mathrm{C}$, at $50 \%$ of soil moisture capacity) of 2.03 for the forest floor and 2.39 for the mineral soil are within the range of 1.4 to 3.8 reported for a variety of temperate forest soils (Schlesinger, 1977; Dorr and Munnich, 1987; Crill, 1991; Kicklighter et al., 1994).

Although many field studies fail to find relationships between soil moisture and $\mathrm{CO}_{2}$ emissions, our results agree with other laboratory studies that found reduced soil respiration rates under very dry or very wet conditions (Linn and Doran, 1984; Doran et al., 1990). A notable result of our incubations was that the influence of moisture was stronger at high temperatures than it was at lower temperatures (Fig. 2). This is relevant in that moisture effects on soil respiration may become more pronounced at higher soil temperatures.

Inclusion of both moisture and temperature in our multiple polynomial models resulted in much better predictions of $\mathrm{CO}_{2}$ emissions than predictions obtained using temperature alone. For the forest floor, the relationship of temperature vs $\ln \left[\mathrm{CO}_{2}\right]$ flux resulted in an $r^{2}$ of 0.47 , approximately half the $r^{2}$ of 0.89 (Table 2) obtained using the full multiple polynomial equation. The enhanced predictive capability that we observed agrees with other field studies in temperate forest soils (e.g. Vogt et al., 1980; 


\section{FOREST FLOOR}
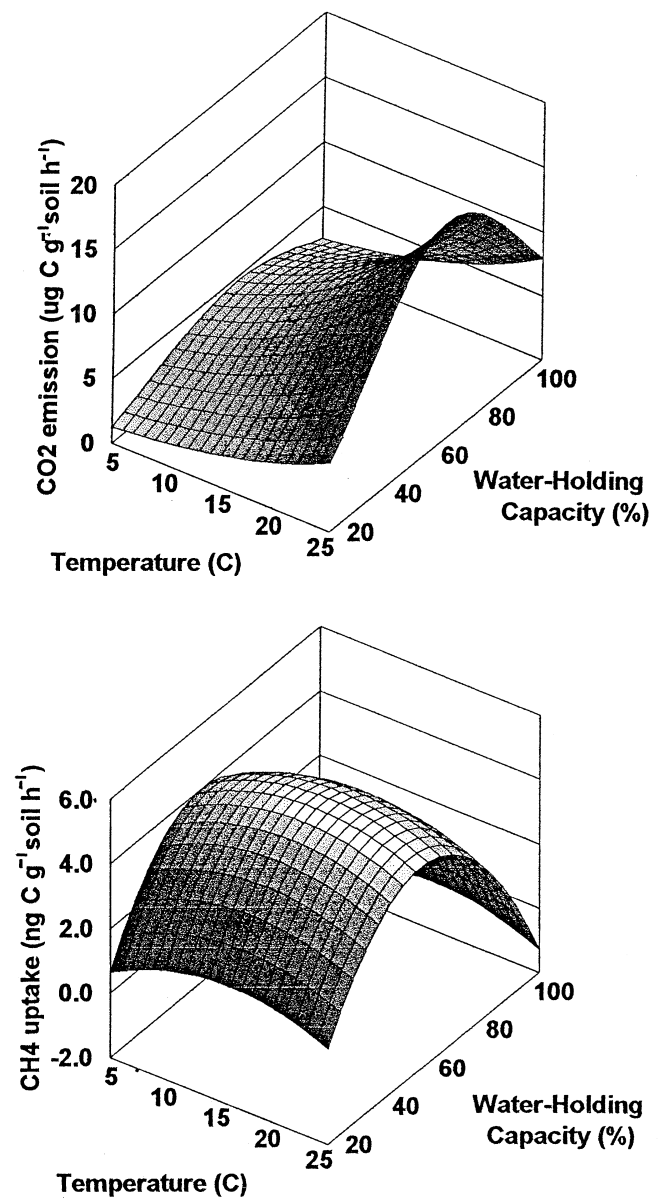

MINERAL SOIL
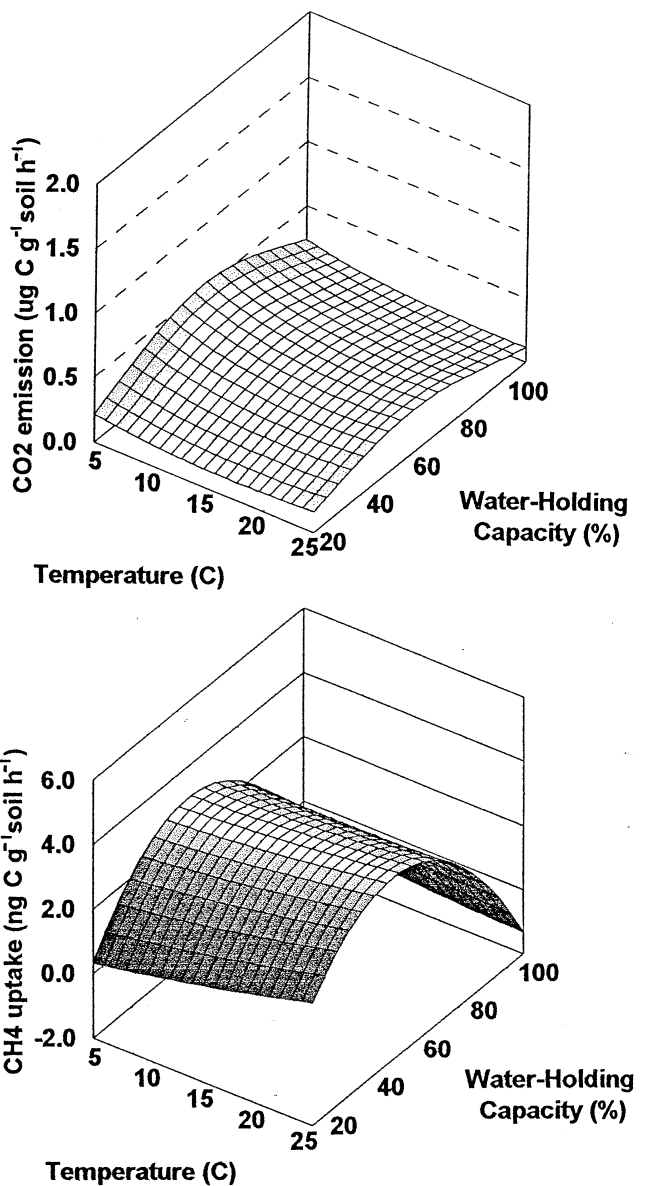

Fig. 2. Multiple polynomial regression models of temperature and moisture used to predict $\mathrm{CO}_{2}$ and $\mathrm{CH}_{4}$ fluxes

Dorr and Munnich, 1987; Weber, 1990; Fernandez et al., 1993; Hanson et al., 1993) and even across global forest datasets (Raich and Schlesinger, 1992). Our model indicates an unexplained weakly-negative relationship between temperature and $\mathrm{CO}_{2}$ effluxes for mineral soil between $5^{\circ}$ and $10^{\circ} \mathrm{C}$. We do not know the reason for this counterintuitive result, but we believe it is a stems from the relatively high variability, even under laboratory conditions, at the very low flux rates in mineral soil.

\section{Methane}

Methane uptake was very strongly correlated with moisture content in mineral soil, as found in other field and laboratory studies (e.g. Whalen et al., 1990; Striegl et al., 1992; Adamsen and King, 1993; Koschorreck and Conrad, 1993; Castro et al., 1995; Yavitt et al., 1995).

In a laboratory-based study on agricultural soils, Nesbit and Breitenbeck (1992) found a response to moisture comparable to ours, with maximum methane uptake observed at approximately $50-70 \%$ of water-filled porespace (WFPS). We calculated porespace volumes for our soils, and found similarly that maximum methane uptake occurred at approximately $60 \%$ of WFPS for both forest floor and mineral soil. We did not, however, express our data on a WFPS basis due to our inability to accurately estimate WFPS. At high moisture contents, using our volumetric water content and bulk density, as well as measured particle density (forest floor: 1.19 ; mineral soil 2.06), WFPS values exceeded $100 \%$ (up to $115 \%$ ). We believe that the presence of considerable organic matter in our soil complicates the ability to calculate WFPS because as organic matter is moistened, it both absorbs moisture and expands into nearby porespaces. Thus, we cannot as accurately determine porespace volume as can be done for soils lower in organic 
Table 1. Polynomial equations used to predict $\ln \left[\mathrm{CO}_{2}\right]$ and $\mathrm{CH}_{4}\left(\mathrm{CO}_{2}: \mu \mathrm{g} \mathrm{Cg}^{-1}\right.$ soil h${ }^{-1} ; \mathrm{CH}_{4}: \mathrm{ng} \mathrm{C}^{-1}$ soil $\left.\mathrm{h}^{-1}\right)$ fluxes for laboratoryincubated forest soil material

\begin{tabular}{|c|c|c|c|c|c|c|c|}
\hline \multirow[b]{2}{*}{ Gas } & \multirow[b]{2}{*}{ Soil material } & \multicolumn{6}{|c|}{ Coefficients for gas flux $=A+B T+C W+D T^{2}+E W^{2}+F(T \times W)$} \\
\hline & & $A$ & $B$ & $C$ & $D$ & $E$ & $F$ \\
\hline \multirow{2}{*}{$\overline{\ln \left[\mathrm{CO}_{2}\right]}$} & forest floor $\left(r^{2}=0.89\right), p<0.0001$ & -0.9851 & $0.0610^{*}$ & $0.0686^{*}$ & 0.00046 & $-0.00052 *$ & -0.00017 \\
\hline & mineral soil $\left(r^{2}=0.62\right), p<0.002$ & -1.8655 & $-0.0954 *$ & $0.0575^{*}$ & 0.0028 & $-0.00048 *$ & 0.00023 \\
\hline \multirow{2}{*}{$\mathrm{CH}_{4}$} & forest floor $\left(r^{2}=0.47\right), p<0.02$ & -3.8087 & $\begin{array}{r}-0.0934 \\
0.2807\end{array}$ & 0.2537 & -0.00875 & -0.00242 & $-0.00008^{*}$ \\
\hline & mineral soil $\left(r^{2}=0.84\right), p<0.0001$ & -2.5179 & 0.0678 & $0.1982 *$ & 0.00082 & $-0.00179 *$ & -0.00117 \\
\hline
\end{tabular}

matter and where particle densities are much closer to 2.65 .

The low $\mathrm{Q}_{10}$ value (1.11) we observed for $\mathrm{CH}_{4}$ uptake by the mineral soil is comparable to weak relationships between $\mathrm{CH}_{4}$ uptake and temperature observed by Born et al. (1990), Nesbit and Breitenbeck (1992) and Koschorreck and Conrad (1993).

A second order polynomial regression of $\mathrm{CH}_{4}$ uptake (by mineral soil) to moisture produced a model with $r^{2}=0.80$. Addition of temperature to the model increased predictability by $5 \%\left(r^{2}=0.84\right)$. This agrees with field work at the Harvard Forest (Bowden et al., 1993), where a multiple linear regression of $\mathrm{CH}_{4}$ fluxes to temperature and moisture showed that these two factors together strongly predicted $\mathrm{CH}_{4}$ uptake $\left(r^{2}=0.80\right)$.

Methane uptake is limited by both biotic and abiotic factors. Work at the Harvard Forest (Castro et al., 1995) and elsewhere (Crill, 1991; Adamsen and King, 1993) found that methane uptake in spring is strongly correlated to soil temperature, but soil moisture is much more closely related to uptake during the growing season. Early in spring, methanotrophs may be metabolically limited by low soil temperatures, but as soils become simultaneously warmer and drier, metabolic limitations are overcome, and uptake activity is then controlled by the ability of $\mathrm{CH}_{4}$ to diffuse to the active methanotrophic sites in mineral soil (Born et al., 1990; Striegl, 1993; Washington et al., 1994). Reduced consumption under dry conditions was probably due to moisture stress on methanotrophs; soils at $20 \%$ WHC were noticeably air-dry. High moisture conditions probably create a physical barrier to gaseous diffusion.

Table 2. Relative change in soil forest floor $\mathrm{CO}_{2}$ efflux and mineral soil $\mathrm{CH}_{4}$ uptake for typical summer soil conditions in response to a $20 \%$ increase in soil temperature $\left(13\right.$ to $15.6^{\circ} \mathrm{C}$ for forest floor; 10 to $12^{\circ} \mathrm{C}$ for mineral soil) and a $20 \%$ decrease in soil moisture (from 60 to $48 \%$ of water-holding capacity)

\begin{tabular}{lcc}
\hline Condition change & $\begin{array}{c}\text { \% Change in forest } \\
\text { floor } \mathrm{CO}_{2} \text { efflux }\end{array}$ & $\begin{array}{c}\% \text { Change in mineral } \\
\text { soil } \mathrm{CH}_{4} \text { uptake }\end{array}$ \\
\hline Warmer & +21.9 & +2.0 \\
Drier & -11.2 & +3.6 \\
Warmer and drier & +8.9 & +7.0 \\
\hline
\end{tabular}

\section{Implications}

We used our models to compare trace gas fluxes during typical summer temperature and moisture conditions to fluxes under conditions of increased soil temperature and decreased soil moisture. We estimated changes in $\mathrm{CO}_{2}$ effluxes by forest floor material and $\mathrm{CH}_{4}$ uptake by mineral soil in response to a $20 \%$ increase in soil temperature and a $20 \%$ decrease in soil moisture, using, as typical conditions, a soil moisture content of $60 \%$ water-holding capacity, and a temperature of $12^{\circ} \mathrm{C}$ for mineral soil and $15^{\circ} \mathrm{C}$ for forest floor. Under warming conditions alone, both $\mathrm{CO}_{2}$ emissions and $\mathrm{CH}_{4}$ uptake increased (Table 2). Under drier conditions, $\mathrm{CO}_{2}$ emissions decreased, but $\mathrm{CH}_{4}$ uptake increased. For both $\mathrm{CO}_{2}$ and $\mathrm{CH}_{4}$, alteration simultaneously of both variables produced relative changes that were markedly different than the additive response of individual variable changes would have predicted; $\mathrm{CO}_{2}$ emissions were $17 \%$ less than would have been predicted and $\mathrm{CH}_{4}$ uptake was $25 \%$ greater than would have been predicted.

We applied the relative flux changes to typical field flux rates during summer, using a $\mathrm{CO}_{2}$ efflux of $12.5 \mathrm{mmol} \mathrm{CO} \mathrm{C}^{-2} \mathrm{~h}^{-1}$ (Peterjohn et al., 1994), and a $\mathrm{CH}_{4}$ uptake of $0.010 \mathrm{mmol} \mathrm{CH}_{4} \mathrm{~m}^{-2} \mathrm{~h}^{-1}$ (Castro et al., 1995), and assumed that all $\mathrm{CO}_{2}$ was emitted by the forest floor and all $\mathrm{CH}_{4}$ was consumed by mineral soil. We also used a global warming $\mathrm{CO}_{2}$ equivalent (GWE) of 26 for $\mathrm{CH}_{4}$ (Lilieveld and Crutzen, 1992). Under typical conditions, combining $\mathrm{CO}_{2}$ emissions and $\mathrm{CH}_{4}$ uptake provides a GWE efflux of $12.24 \mathrm{mmol} \mathrm{CO}_{2} \mathrm{~m}^{-2} \mathrm{~h}^{-1}$. Under warmer and drier conditions, the summer soil GWE flux increases by $1.09 \mathrm{mmol} \mathrm{CO}_{2} \mathrm{~m}^{-2} \mathrm{~h}^{-1}$. This represents an increase of $8.9 \%$ over the current GWE emissions during typical summer soil conditions. Clearly other factors must be considered in producing final estimates as illustrated by Jenkinson et al. (1991) and Lloyd and Taylor (1994), but our results indicate that single-factor equations used to predict exchanges in fluxes of greenhouse gases between soils and the atmosphere may be insufficient to predict changes in trace gas fluxes, and that inclusion of both moisture and temperature in models of trace gas fluxes can increase the accuracy of trace 
gas budgets and can enhance assessments of trace gas fluxes under models of climate change.

Acknowledgements - This research was supported by the Northeast Regional Center of the Department of Energy National Institute for Global Environmental Change (NIGEC), by a NIGEC fellowship to GMR and by support from Allegheny College and the Harvard Forest. We thank Chris Catricala, Rich Boone, Reto Stocker and Sam Reese for laboratory assistance, Mark Castro for editorial assistance, and a host of undergraduate students ( $\mathrm{N}$. Ajanovic, G. Garcia, K. McCracken, C. Millikin, N. Oehm, J. Sorenson, J. Taggart) for contributions in the field and laboratory. This research is a contribution to the Northeast Regional Center of NIGEC, and to the Harvard Forest Long-Term Ecological Research Program.

\section{REFERENCES}

Adamsen A. P. S. and King G. M. (1993) Methane consumption in temperate and subarctic forest soils: rates, vertical zonation, and responses to water and nitrogen. Applied and Environmental Microbiology 59, 485-490.

Bedard C. and Knowles R. (1989) Physiology, biochemistry, and specific inhibitors of $\mathrm{CH}_{4}, \mathrm{NH}_{4}^{+}$, and $\mathrm{CO}$ oxidation by methanotrophs and nitrifiers. Microbiological Review 53, 68-84.

Bowden R. D., Castro M. S., Melillo J. M., Steudler P. A. and Aber J. D. (1993) Fluxes of greenhouse gases between soils and the atmosphere in a temperate forest following a simulated hurricane blowdown. Biogeochemistry 21, 61-71.

Born M., Dorr H. and Levin I. (1990) Methane consumption in aerated soils of the temperate zone. Tellus $\mathbf{4 2 B}$, $2-8$.

Castro M. S., Melillo J. M., Steudler P. A. and Chapman J. W. (1994) Soil moisture as a predictor of methane uptake by temperate forest soils. Canadian Journal of Forest Research 24, 1805-1810.

Castro M. S., Steudler P. A., Melillo J. M., Aber J. D. and Bowden R. D. (1995) Factors controlling atmospheric methane consumption by temperate forest soils. Global Biogeochemical Cycles 9, 1-10.

Crill P. M. (1991) Seasonal patterns of methane uptake and carbon dioxide release by a temperate woodland soil. Global Biogeochemical Cycles 5, 319-334.

Doran, J. W., Mielke, L. N. and Power, J. F. (1990) Microbial activity as regulated by soil water-filled pore space. In Transactions 14th International Congress of Soil Science, 1990, pp. 94-99.

Dorr H. and Munnich K. O. (1987) Annual variation in soil respiration in selected areas of the temperate zone. Tellus 39B, 114-121.

Fernandez I. J., Son Y., Kraske C. R., Rustad L. E. and David M. B. (1993) Soil carbon dioxide characteristics under different forest types and after harvest. Soil Science Society of America Journal 57, 1115-1121.

Groffman P. M., Gold A. J. and Simmons R. C. (1992) Nitrate dynamics in riparian forests: microbial studies. Journal of Environmental Quality 21, 666-671.

Hanson P. J., Wullschleger S. D., Bohlman S. A. and Todd D. E. (1993) Seasonal and topographic patterns of forest floor $\mathrm{CO}_{2}$ efflux from an upland oak forest. Tree Physiology 31, 1-5.

Jenkinson D. S., Adams D. E. and Wild A. (1991) Model estimates of $\mathrm{CO}_{2}$ emissions from soil in response to global warming. Nature 351, 304-306.

Kicklighter D. W., Melillo J. M., Peterjohn W. T., Rastetter E. B., McGuire A. D. and Steudler P. A. (1994) Aspects of spatial and temporal aggregation in estimating regional carbon dioxide fluxes from tem- perate forest soils. Journal of Geophysical Research 99, 1303-1315.

Koschorreck M. and Conrad R. (1993) Oxidation of atmospheric methane in soil: measurements in the field, in soil cores, and in soil samples. Global Biogeochemical Cycles 7, 109-121.

Lessard R., Rochette P., Topp E., Pattey E., Desjardins R. L. and Beaumont G. (1994) Methane and carbon dioxide fluxes from poorly drained adjacent cultivated and forest sites. Canadian Journal of Soil Science $\mathbf{7 3 ,}$ 139-146.

Lilieveld J. and Crutzen P. J. (1992) Indirect chemical effects of methane on global warming. Nature 355, 339342.

Linn D. M. and Doran J. W. (1984) Effect of water-filled pore space on carbon dioxide and nitrous oxide production in tilled and non-tilled soils. Soil Science Society of America Journal 48, 1267-1272.

Lloyd J. and Taylor J. A. (1994) On the temperature dependence of soil respiration. Functional Ecology 8, 315-323.

Magill A. H., Aber J. D., Hendricks J. J., Bowden R. D., Melillo J. M. and Steudler P. A. (1997) Biogeochemical response of forest ecosystems to simulated chronic nitrogen deposition. Ecological Applications 7, 402-415.

Melillo, J. M., Steudler, P. A., Aber, J. D. and Bowden, R. D. (1989) Atmospheric deposition and nutrient cycling. In Exchange of Trace Gases between Terrestrial Ecosystems and the Atmosphere, eds M. O. Andreae and D. Schimel, pp. 263-280. Wiley, New York.

Mooney H. A., Vitousek P. M. and Matson P. A. (1987) Exchange of materials between terrestrial ecosystems and the atmosphere. Science 238, 926-932.

Nesbit S. P. and Breitenbeck G. A. (1992) A laboratory study of factors influencing methane uptake by soils. Agriculture, Ecosystems and Environment 41, 39-54.

Peterjohn W. J., Melillo J. M., Steudler P. A., Newkirk K. M., Bowles F. P. and Aber J. D. (1994) Responses of trace gas fluxes and $\mathrm{N}$ availability to experimentally elevated soil temperatures. Ecological Applications 4, 617625.

Prather, M., Derwent, R., Ehhalt, D., Fraser, P., Sanhueza, E., and Zhou, X. (1996) Radiative forcing of climate change: Other gases and atmospheric chemistry. In Climate Change 1995: The Science of Climate Change, eds J. T. Houghton, L. G. Meira Filho, B. A Callander, N. Harris, A. Kaltenberg and K. Marshell, pp. 86-103. Cambridge University Press, Cambridge.

Raich J. W. and Schlesinger W. H. (1992) The global carbon dioxide flux in soil respiration and its relationship to vegetation and climate. Tellus 44B, 81-99.

Schimel, D., Alves, D., Enting, I., Heimann, M., Joos, F., Raynard, D. and Wigley, T. (1996) Radiative forcing of climate change: $\mathrm{CO}_{2}$ and the carbon cycle. In Climate Change 1995: The Science of Climate Change, eds J. T. Houghton, L. G. Meira Filho, B. A. Challander, H. Harris, A. Kaltenberg and K. Marshell, pp. 76-86. Cambridge University Press, Cambridge.

Schlesinger W. H. (1977) Carbon balance in terrestrial detritus. Annual Review of Ecology and Systematics 8, 5181 .

Schutz, H., Seiler, W. and Rennenberg, H. (1990) Soil and land use related sources and sinks of methane $\left(\mathrm{CH}_{4}\right)$ in the context of the global methane budget. In Soils and the Greenhouse Effect, ed. A. F. Bouwman, pp. 269-285. Wiley, New York.

Steudler P. A., Bowden R. D., Melillo J. M. and Aber J. D. (1989) Influence of nitrogen fertilization on methane uptake in temperate forest soils. Nature 341, 314-316.

Striegl R. G. (1993) Diffusional limits to the consumption of atmospheric methane by soils. Chemosphere 26, 715 720 . 
Striegl R. G., McConnaughey T. A., Thorstenson D. C., Weeks E. P. and Woodward J. C. (1992) Consumption of atmospheric methane by desert soils. Nature 357, 145-147.

Thompson A. M. (1992) The oxidizing capacity of the Earth's atmosphere: probable past and future changes. Science 256, 1157-1165.

Vogt K. A., Edmonds R. L., Antos G. C. and Vogt D. J. (1980) Relationships between $\mathrm{CO}_{2}$ evolution, ATP concentrations and decomposition in four forest ecosystems in western Washington. Oikos 35, 72-79.

Washington J. W., Rose A. W., Ciolkosz E. J. and Dobos R. R. (1994) Gaseous diffusion and permeability in four soil profiles in central Pennsylvania. Soil Science 157, 65-76.

Watson R. T., Rodhe H., Oeschger H. and Siegenthaler U. (1990) Greenhouse gases and aerosols. In Climate
Change: The IPCC Scientific Assessment, eds J. T. Houghton, G. J. Jenkins and J. J. Ephraums, pp. 1-40. Cambridge University Press.

Weber M. G. (1990) Forest soil respiration after cutting and burning in immature aspen ecosystems. Forest Ecology and Management 31, 1-14.

Whalen S. C., Reeburgh W. S. and Sandbeck K. A. (1990) Rapid methane oxidation in a landfill cover soil. Applied and Environmental Microbiology 56, 3405-3411.

Wiant H. V. Jr. (1967) The influence of temperature on the rate of soil respiration. Journal of Forestry 65, 489490.

Yavitt J. B., Fahey T. J. and Simmons J. A. (1995) Methane and carbon dioxide dynamics in a northern hardwood ecosystem. Soil Science Society of America Journal 59, 796-804. 